\title{
Uji Potensi Ekstrak Daun Pepaya (Carica papaya linn) sebagai Larvasida terhadap Larva Aedes sp. Di Manado
}

\author{
Nazzirah A. Ammari, ${ }^{1}$ Greta J. P. Wahongan, ${ }^{2}$ Janno B. B. Bernadus ${ }^{3}$ \\ ${ }^{1}$ Program Studi Pendidikan Dokter Fakultas Kedokteran Universitas Sam Ratulangi \\ Manado, Indonesia \\ ${ }^{2}$ Bagian Parasitologi Fakultas Kedokteran Universitas Sam Ratulangi Manado, Indonesia \\ Email: nazzirahal@ymail.com
}

\begin{abstract}
Papaya leaf extract as a natural larvicide can be used as an alternative to control resistant Aedes aegypti populations. The benefits of controlling the dengue hemorrhagic fever (DHF) vektor are reducing the level of morbidity, mortality and suffering of individuals and their families. This research was conducted with a simple laboratory experimental method. Used papaya leaves extract and larvae of Aedes sp. instar III and IV taken in water float. This study used 100 larvae divided into 2 groups with positive groups, namely the concentration of $5 \mathrm{gr}, 10 \mathrm{gr}, 15 \mathrm{gr}$ and $20 \mathrm{gr}$ and a control group that only used aquadesh which was repeated twice. This study aimed to determine the potential of papaya leaf extract (Carica Papaya Linn) as a larvicide against larvae of Aedes sp. in Manado. In conclusion, papaya leaf extract (Carica Papaya Linn) has potential as a larvicide against Aedes sp. Larvae. where the higher the extract concentration given, so the mortality rate of Aedes sp. larvae higher.
\end{abstract}

Keyword : Papaya Leaves (Carica Papaya Linn), Larvacides, Larvae Aedes sp.

\begin{abstract}
Abstrak: Ekstrak daun pepaya sebagai larvasida alami dapat digunakan sebagai salah satu alternatif untuk mengendalikan populasi Aedes aegypti yang telah resisten. Manfaat dari pengendalian vektor penyakit demam berdarah dengue (DBD) adalah mengurangi tingkat kesakitan, kematian, dan penderitaan individu beserta keluarganya. Tujuan penelitian ini untuk mengetahui potensi ekstrak daun papaya (Carica Papaya Linn) sebagai larvasida terhadap larva Aedes sp. di Manado. Penelitian ini dilakukan dengan metode eksperimental laboratoris sederhana. Menggunakan ekstrak daun pepaya dan larva Aedes sp. instar III dan IV yang di ambil di penampungan air. Penelitian ini menggunakan 100 ekor larva yang terbagi atas 2 kelompok dengan kelompok uji yaitu konsentrasi 5gr, 10 gr, 15 gr dan 20 gr serta kelompok control yang hanya menggunakan aquadesh yang diulangi sebanyak dua kali percobaan. Hasil nilai $\mathrm{p}$ yang didapat dari uji Kruskall Wallis memiliki nilai $\mathrm{p}<0.05$, hal ini menunjukkan bahwa terdapat perbedaan tingkat kematian larva Aedes sp. setelah 6 jam, 12 jam, 18 jam dan 24 jam pada berbagai konsentrasi perlakuan. Sebagai simpulan, ekstrak daun papaya (Carica Papaya Linn) memiliki potensi sebagai larvasida terhadap larva Aedes sp. dimana semakin tinggi konsentrasi ekstrak yang diberikan maka semakin tinggi pula tingkat kematian larva Aedes sp.
\end{abstract}

Kata Kunci : Daun Pepaya (Carica Papaya Linn), Larvasida, Larva Aedes sp.

\section{PENDAHULUAN}

Di Indonesia terdapat dua vektor nyamuk Aedes sp. penyebab DBD (Demam Berdarah Dengue) yaitu Aedes aegypti sebagai vektor utama dan Aedes albopictus sebagai vektor potensial. $^{1}$ Dimana menurut World Health
Organization (WHO), Indonesia termasuk negara dengan kasus demam berdarah tertinggi di Asia Tenggara, dengan ratarata $95 \%$ kasus terjadi pada anak dengan usia di bawah 15 tahun. ${ }^{2}$ Merupakan salah satu provinsi endemis DBD di Indonesia, Sulawesi Utara menurut data Dinas 
Kesehatan, mencatat 1237 kasus dengan 15 orang diantaranya meninggal dunia pada tahun 2012 dan 273 kasus dengan jumlah kematian 5 orang pada Januari $2013 .^{3}$

Dengan tingginya kasus yang terjadi, maka pemanfaatan dari pengendalian vektor penyakit demam berdarah dengue (DBD) adalah hal yang sangat penting untuk dilakukan mengingat belum adanya obat maupun vaksin dari penyakit $\mathrm{DBD},{ }^{4}$ dimana manfaat dari pengendalian DBD sendiri dapat mengurangi tingkat kesakitan, kematian, dan penderitaan yang dialami individu beserta keluarganya. Secara garis besar, pengendalian DBD juga dapat menurunkan kerugian sosial dan meningkatkan produktivitas masyarakat dengan berbagai "multiple effect" yang lain. Dengan begini, jika kita melakukan pengendalian vektor penyakit DBD maka akan meningkatan kualitas mutu kehidupan. ${ }^{5}$

Salah satu upaya yang sudah dilakukan untuk mengendalikan vektor nyamuk yaitu dengan penggunaan larvasida. ${ }^{6}$ Larvasida yg digunakan saat ini berasal dari bahan sintetis. Dimana dampak dari bahan sintesis ini dapat menyebabkan matinya organisme yang bukan menjadi sasaran dan menjadi bahan kimia yang tidak dapat dihancurkan oleh alam.

Berdasarkan dampak negatif tadi maka penggunaan bahan sintetik mulai dibatasi, dan beralih ke larvasida dari bahan alami. $^{7}$ Ekstrak daun pepaya sebagai larvasida alami dapat digunakan sebagai salah satu alternatif untuk mengendalikan vektor DBD. ${ }^{6}$ Karena enzim dalam kandungan daun pepaya seperti enzim papain, saponin, flavonoid, dan alkaloid karpain memiliki potensi sebagai larvasida. ${ }^{8}$

Dengan melihat latar belakang yang telah dipaparkan maka peneliti merasa perlu untuk dilakukan penelitian mengenai pengaruh ekstrak daun papaya (Carica Papaya Linn) terhadap larva Aedes sp. yang terdapat di Manado
Sulawesi Utara untuk mengetahui tingkat kemampuan dari daun papaya terhadap mortalitas larva nyamuk Aedes $s p$

\section{METODE PENELITIAN}

Penelitian ini dilakukan dengan metode eksperimental laboratoris sederhana pada bulan Oktober 2020 Desember 2020. Sampel diambil secara acak di penampungan air atau perindukan larva di beberapa tempat di Kota Manado, dengan kriteria larva nyamuk Aedes sp. instar III atau IV yang hidup dan bergerak aktif.

Pembuatan ekstrak daun pepaya menggunakan \pm 500 gram daun papaya yang sudah dicuci dan dipotong kecilkecil. Lalu dikeringkan menggunakan microwave hingga kering kemudian diblender hingga menjadi serbuk. Serbuk ditapis menggunakan saringan lalu ditimbang untuk di masukan di tiap-tiap gelas dengan konsentrasi $5 \mathrm{gr}, 10 \mathrm{gr}, 15 \mathrm{gr}$, dan 20gr. Setiap gelas yang telah diberikan konsentrasi ekstrak daun pepaya dicampurkan dengan aquadesh sesuai takaran dari masing-masing konsentrasi daun pepaya, kemudian diaduk. Setelah diaduk, daun pepaya disaring menggunakan kain lalu diperas. Hasil perasan tersebut disaring lagi menggunakan kertas saring untuk mendapakan konsentrasi ekstrak daun pepaya.

Pengujian larva menggunakan 100 ekor dengan melakukan percobaan sebanyak 2 kali. Sebanyak 10 ekor larva Aedes sp. dimasukkan di masing-masing gelas yang berisi konsentrasi. Kemudian diamati jumlah larva yang mati dengan kriteria larva tidak bergerak sebelum dan sesudah diberi rangsangan (disentuh dengan sendok).

Hasil pengamatan yang diperoleh dianalisa dengan menggunakan uji analisis ANOVA, agar dapat mengetahui adanya perbedaan rata-rata kematian larva nyamuk disetiap perlakuan yang diberikan. Penyajian data dilakukan 
secara deskriptif dalam bentuk tabel secara analitik.

Perhitungan persentase kematian larva menggunakan rumus:

$$
\text { Mortalitas (\%) }=\frac{\text { Kematian Larva }}{\text { Jumlah Larva }} \times 100 \%
$$

Kemudian dilakukan uji dengan menggunakan analisis Probit daun pepaya terhadap larva Aedes sp. untuk mengetahui Lethal Concentration (LC50 dan LC90) dan Lethal Time (LT50 dan LT90).

\section{HASIL PENELITIAN}

Tabel 1. Persentase Kematian Larva Aedes sp. Setelah Pemberian Beberapa Konsentrasi Ekstrak Daun Pepaya (Carica Papaya Linn) Setelah 6 Jam.

\begin{tabular}{|c|c|c|c|c|c|}
\hline \multirow[t]{2}{*}{ Konsentrasi } & \multirow{2}{*}{$\begin{array}{c}\text { Jumlah } \\
\text { Larva } \\
\text { Bahan } \\
\text { Uji }\end{array}$} & \multicolumn{2}{|c|}{ Replikasi } & \multicolumn{2}{|c|}{$\begin{array}{c}\text { Kematian } \\
\text { larva setelah } \\
6 \text { jam } \\
\text { perlakuan }\end{array}$} \\
\hline & & I & II & Rerata & $\%$ \\
\hline $5 \mathrm{gr}$ & 10 & 0 & 0 & 0 & 0 \\
\hline $10 \mathrm{gr}$ & 10 & 0 & 1 & 0,5 & 10 \\
\hline $15 \mathrm{r}$ & 10 & 0 & 1 & 0,5 & 10 \\
\hline $20 \mathrm{gr}$ & 10 & 2 & 2 & 2 & 40 \\
\hline Kontrol & 10 & 0 & 0 & 0 & 0 \\
\hline
\end{tabular}

Tabel 2. Persentase Kematian Larva Aedes sp. Setelah Pemberian Beberapa Konsentrasi Ekstrak Daun Pepaya (Carica Papaya Linn) Setelah 12 Jam

\begin{tabular}{|c|c|c|c|c|c|}
\hline \multirow[t]{2}{*}{ Konsentrasi } & \multirow{2}{*}{$\begin{array}{c}\text { Jumlah } \\
\text { Larva } \\
\text { Bahan } \\
\text { Uji }\end{array}$} & \multicolumn{2}{|c|}{ Replikasi } & \multicolumn{2}{|c|}{$\begin{array}{c}\text { Kematian } \\
\text { larva setelah } \\
6 \text { jam } \\
\text { perlakuan } \\
\end{array}$} \\
\hline & & I & II & Rerata & $\%$ \\
\hline $5 \mathrm{gr}$ & 10 & 0 & 0 & 0 & 0 \\
\hline $10 \mathrm{gr}$ & 10 & 1 & 1 & 1 & 20 \\
\hline $15 r$ & 10 & 2 & 4 & 3 & 60 \\
\hline $20 \mathrm{gr}$ & 10 & 2 & 5 & 3,5 & 70 \\
\hline Kontrol & 10 & 0 & 0 & 0 & 0 \\
\hline
\end{tabular}

Tabel 3. Persentase Kematian Larva Aedes sp. Setelah Pemberian Beberapa Konsentrasi Ekstrak Daun Pepaya (Carica Papaya Linn) Setelah 18 Jam

\begin{tabular}{|c|c|c|c|c|c|}
\hline \multirow[t]{2}{*}{ Konsentrasi } & \multirow{2}{*}{$\begin{array}{c}\text { Jumlah } \\
\text { Larva } \\
\text { Bahan } \\
\text { Uji }\end{array}$} & \multicolumn{2}{|c|}{ Replikasi } & \multicolumn{2}{|c|}{$\begin{array}{c}\text { Kematian } \\
\text { larva setelah } \\
6 \text { jam } \\
\text { perlakuan }\end{array}$} \\
\hline & & I & II & Rerata & $\%$ \\
\hline $5 \mathrm{gr}$ & 10 & 0 & 1 & 0,5 & 10 \\
\hline $10 \mathrm{gr}$ & 10 & 1 & 3 & 2 & 40 \\
\hline $15 r$ & 10 & 1 & 2 & 1,5 & 30 \\
\hline $20 \mathrm{gr}$ & 10 & 3 & 1 & 2 & 40 \\
\hline Kontrol & 10 & 0 & 0 & 0 & 0 \\
\hline
\end{tabular}

Tabel 4. Persentase Kematian Larva Aedes sp. Setelah Pemberian Beberapa Konsentrasi Ekstrak Daun Pepaya (Carica Papaya Linn) Setelah 24 Jam

\begin{tabular}{cccccc}
\hline & Jumlah & & \multicolumn{3}{c}{ Kematian } \\
larva setelah \\
Konsentrasi & $\begin{array}{c}\text { Larva } \\
\text { Bahan } \\
\end{array}$ & Uji & Replikasi & \multicolumn{3}{c}{$\begin{array}{c}6 \text { jam } \\
\text { perlakuan }\end{array}$} \\
\cline { 3 - 6 } & & I & II & Rerata & $\%$ \\
\hline 5gr & 10 & 0 & 0 & 0 & 0 \\
$10 \mathrm{gr}$ & 10 & 1 & 1 & 1 & 20 \\
$15 \mathrm{r}$ & 10 & 1 & 2 & 1,5 & 30 \\
$20 \mathrm{gr}$ & 10 & 1 & 1 & 1 & 20 \\
Kontrol & 10 & 0 & 0 & 0 & 0 \\
\hline
\end{tabular}

Berdasarkan data hasil uji normalitas pada salah satu kelompok konsentrasi tidak berdistribusi normal karena jumlah sampel $<50$, maka uji one way ANOVA tidak dapat dilakukan sehingga dilakukan uji Kruskall Wallis. Kemudian nilai $\mathrm{p}$ yang didapat dari uji Kruskall Wallis memiliki nilai $\mathrm{p}<0.05$, hal ini menunjukkan bahwa terdapat perbedaan tingkat kematian larva Aedes sp. setelah 24 jam pada berbagai konsentrasi perlakuan.

Kemudian dilakukan uji Post Hoc untuk mengetahui adanya perbedaan ratarata kematian larva antar dua kelompok perlakuan, pengujian ini dilakukan menggunakan uji Mann Whitney. Nilai p dari Mann Whitney yang memiliki nilai $\mathrm{p}$ $<0.05$ adalah pada kelompok konsentrasi $5 \mathrm{gr}$ dan $10 \mathrm{gr}$, konsentrasi $5 \mathrm{gr}$ dan $15 \mathrm{gr}$, konsentrasi 5gr dan 20gr, 10gr dan 
control, 15gr dan control, 20gr dan control. Dengan demikian dapat dikatakan bahwa konsentrasi $5 \mathrm{gr}$ dan konsentrasi pada kelompok control memiliki perbedaan signifikan dengan konsentrasi $10 \mathrm{gr}, 15 \mathrm{gr}$, dan 20gr. Sedangkan antara konsentrasi $10 \mathrm{gr}, 15 \mathrm{gr}$, dan $20 \mathrm{gr}$ tidak ada perbedaan tingkat yang signifikan.

Tabel 5. Konsentrasi Berdasarkan Hasil Analisis Probit

\begin{tabular}{ccc}
\hline $\begin{array}{c}\text { Konsentrasi } \\
\text { Letal }\end{array}$ & $\begin{array}{c}\text { Tingkat } \\
\text { Kepercayaan }\end{array}$ & Estimasi \\
\hline LC $_{50}$ & $95,0 \%$ & 17,263 \\
LC $_{90}$ & $95,0 \%$ & 38,900 \\
\hline
\end{tabular}

Tabel 6. Hasil Analisis Probit Untuk Lethal Time

\begin{tabular}{cccc}
\hline $\begin{array}{c}\text { Konsentras } \\
\mathrm{i}\end{array}$ & $\begin{array}{c}\text { Wakt } \\
\mathrm{u} \\
\text { Letal }\end{array}$ & $\begin{array}{c}\text { Tingkat } \\
\text { Kepercayaa }\end{array}$ & Estimasi \\
& $\mathrm{n}$ & \\
\hline \multirow{2}{*}{$\mathrm{gr}$} & $\mathrm{LT}_{50}$ & $95,0 \%$ & 242,46 \\
& $\mathrm{LT}_{90}$ & $95,0 \%$ & 2 \\
& & & 399,61 \\
\multirow{3}{*}{ 10gr } & $\mathrm{LT}_{50}$ & $95,0 \%$ & 95,172 \\
& $\mathrm{LT}_{90}$ & $95,0 \%$ & 252,32 \\
& & & 4 \\
$15 \mathrm{gr}$ & $\mathrm{LT}_{50}$ & $95,0 \%$ & 58,158 \\
& $\mathrm{LT}_{90}$ & $95,0 \%$ & 215,31 \\
& & & 0 \\
$20 \mathrm{gr}$ & $\mathrm{LT}_{50}$ & $95,0 \%$ & 25,675 \\
& $\mathrm{LT}_{90}$ & $95,0 \%$ & 182,82 \\
& & & 8 \\
Kontrol & $\mathrm{LT}_{50}$ & $95,0 \%$ & 507,45 \\
& $\mathrm{LT}_{90}$ & $95,0 \%$ & 8 \\
& & & 664,55 \\
& & & 3 \\
\hline
\end{tabular}

Dari tabel 6 diketahui bahwa semakin besar konsentrasi maka nilai $\mathrm{LT}_{50}$ dan $\mathrm{LT}_{90}$ nya semakin kecil.

\section{BAHASAN}

Pada penelitian ini didapatkan uji Kruskall Wallis yang menyatakan bahwa terdapat perbedaan yang bermakna $(\mathrm{p}<$ $0,05)$ antara seluruh konsentrasi terhadap control, hal ini dapat menjadi bukti bahwa daun pepaya (Carica Papaya Linn) memiliki efek larvisida terhadap Aedes $s p$.

Hasil Uji analisis probit untuk menilai LC tercantum pada tabel. Dimana terdapat banyak penelitian yang telah dilakukan dan memiliki hasil yang berbeda dengan penelitian ini. Perbedaan ini terjadi karena pada beberapa penelitian yang telah terjadi memiliki sampel larutan penguji daun pepaya yang didapat dari proses penyulingan berbeda.

Uji analisis probit untuk menilai LT tercantum pada tabel. Pada beberapa penelitian terdapat perbedaan Lethal Time. Perbedaan itu dipengaruhi beberapa faktor seperti faktor biologi, lokasi, umur tumbuhan, dan juga faktor kimia berupa jenis senyawa aktif dan jenis pelarut yang digunakan dalam ekstraksi.

Adanya beberapa perbedaan hasil penelitian dengan penelitian sebelumnya, yang terjadi karena beberapa faktor. Diantaranya adalah faktor biologi, faktor kimia dan metode ekstraksi. Dimana faktor biologi dipengaruhi oleh lokasi tumbuhan asal, varietas pepaya, spesies, umur tumbuhan dan bagian tumbuhan yang digunakan. Lalu ada faktor kimia, yaitu faktor yang mempengaruhi jenis senyawa, kuantitas dan kualitas dari senyawa kimia yang terkandung didalamnya. Terkahir ada metode ekstraksi, dimana alat-alat yang digunakan menjadi perbedaan hasil akhir dari pengujian seperti perbedaan alat, kekerasan bahan, pelarut yang digunakan dan ukuran bahan. ${ }^{8}$

Berbagai konsentrasi yang diduga menyebabkan kematian larva karena memiliki kandungan aktif seperti flavonoid, tanin, dan alkaloid yang berakibat langsung denga larva Aedes aegypti. ${ }^{9}$

Berdasarkan studi Cania dan Setyaningrum, flavonoid mampu membuat larva tidak dapat bernapas dan mati dengan cara masuk ke dalam tubuh larva melalui sistem respirasi yang kemudian menyebabkan kelayuan pada syaraf serta kerusakan pada sistem 
repirasi. Senyawa flavonoid juga dapat merubah posisi tubuh larva menjadi tidak normal dengan masuk melalui siphon yang menyebabkan kerusakan. ${ }^{10}$

Menurut studi Lapu dan Nganro, metabolisme sel larva dapat terganggu dan akan kekurangan nutrisi, jika enzim terikat oleh tanin karena enzim tersebut akan menjadi lambat. Selain itu, proses penyerapan protein akan terganggu karena tanin mengganggu serangga dalam proses mencerna makanan, dimana tanin mengikat protein dalam sistem pencernaan. ${ }^{11}$

Berdasarkan studi yang dilakukan Kurniawan et al sebagai larvasida, cara kerja alkaloid yaitu sebagai racun perut dengan menghambat daya makan larva. ${ }^{12}$ Dikatakan juga bahwa alkaloid memiliki sifat yang toksik dan apabila digunakan dalam jumlah yang melewati batas maka akan menimbulkan kelumphan saraf, terhentinya sistem saraf dan penekanan jantung, hingga kematian pada larva. ${ }^{7}$

Dalam melakukan penelitian ini tidak dilakukan teknik isolasi. Teknik isolasi berfungsi agar dapat memisahakan senyawa-senyawa aktif. Oleh karena itu, tidak dapat dipastikan bahwa senyawa mana yang berpotensi sebagai larvasida. Adapun kematian larva terjadi karena komponen dari senyawa aktif yang terus bekerja secara resultan. ${ }^{8}$ Pada penelitian ini juga tidak digunakannya etanol, dengan tujuan untuk melihat cara kerja ekstrak daun pepaya murni tanpa bantuan pelarut alkohol.

\section{SIMPULAN}

Ekstrak daun papaya (Carica Papaya Linn) memiliki potensi sebagai larvasida terhadap larva Aedes sp. dimana semakin tinggi konsentrasi ekstrak yang diberikan maka semakin tinggi pula tingkat kematian larva Aedes sp. Konsentrasi ekstrak daun papaya (Carica Papaya Linn) yang berpengaruh membasmi $50 \%$ larva dalam kurun waktu 24 jam ialah konsentrasi 17.263gr.

\section{SARAN}

Untuk peneliti selanjutnya dapat melakukan penelitian dengan konsentrasi yang lebih tinggi untuk melihat konsentrasi yang lebih cepat tanpa menggunakan etanol untuk mematikan larva Aedes sp. dengan kurun waktu yang lebih cepat.

\section{Konflik Kepentingan}

Penulis menyatakan tidak terdapat konflik kepentingan dalam studi ini.

\section{DAFTAR PUSTAKA}

1. Ottay RI. Prevalensi Demam Berdarah Dengue Di Wilayah Kerja Puskesmas Tuminting Tahun 2012-2014. KESMAS 2014;1-4.

2. Jacob, A., Pijoh, V. D., \& Wahongan GJP. Ketahanan hidup dan pertumbuhan nyamuk Aedes spp pada berbagai jenis air perindukan. eBiomedik. 2014;2.

3. Ristanto, F., Kaunang, W. P., \& Pandelaki AJ. Pemetaan kasus demam berdarah dengue di Kabupaten Minahasa Utara. J Kedokt Komunitas Dan Trop. 2015;3(2).

4. Hidayati A. Densitas Vektor Dengue dan Metode Pengendalian Pilihan Keluarga (C) 2018 Program Studi S-1 Kesehatan Masyarakat Universitas Muhammadiyah Semarang Pendahuluan Metode Hasil. 2018;13:17-22.

5. Sukana B. Pemberantasan Vektor DBD di Indonesia. Media Penelit dan Pengemb Kesehat. 1993;3(1).

6. Ramayanti I, Febriani R. Uji Efektivitas Larvasida Ekstrak Daun Pepaya (Carica papaya Linn) terhadap Larva Aedes aegypti. Syifa' Med J Kedokt dan Kesehat. 2016;6(2):79.

7. Adnyani IGAP, Sudarmaja IM. Pengaruh Konsentrasi Ekstrak Etanol Daun Pepaya (Carica Papaya L) Terhadap Kematian Larva Nyamuk Aedes Aegypti. 
12 eBiomedik, Volume 9, Nomor 1, Januari-Juni 2021, hlm.7-12

E-Jurnal Medika 2017;6(11): 112-115.

8. Shadana M, Lesmana SD, Hamidy MY. Efek Larvasida Ekstrak Etanol Daun Pepaya (Carica papaya) Terhadap Larva Aedes aegypti. J online Mhs Univ Riau. 2014;1(2):1-14

9. Gautam K, Kumar P PS. Larvicidal activity and GC-MS analysis of flavonoids of Vitex negundo and Andrographis paniculata against two vector mosquitoes Anopheles stephensi and Aedes aegypti. J Vector Borne. 2013;50(9):171-8.

10. Eka, Cania. ES. Uji efektivitas larvasida ekstrak daun legundi
(Vitex trifolia) terhadap larva Aedes aegypti. Med J Lampung Univ. 2013;2(4):52-60.

11. Lapu P, Nganro N. Pengaruh in Vitro Ekstrak Daun Mimba (Azadiractha indica) terhadap Bakteri Patogen Udang Windu Vibrio alginolyticus. Biosains. 2001;6(2):49-53.

12. Kurniawan, B., Rapina, R., Sukohar, A., \& Nareswari S. Effectiveness Of the pepaya leaf (Carica Papaya Linn) ethanol extract as larvacide for Aedes aegypti Instar III. J Major. 2015;4(5):7684 